\title{
ADAPTIVE NEURO-FUZZY INFERENCE SYSTEM FOR ESTIMATION OF WATER QUALITY INDEX IN DUHOK CAMPS
}

\author{
Amera Ismail Melhum and JWAn AbDulKhaliQ MoHammed \\ Dept. of Computer Science, College of Science, University of Duhok, Kurdistan Region-Iraq
}

(Received: January 30, 2019; Accepted for Publication: June 11, 2019)

\begin{abstract}
The most appropriate method of communicating water quality situation of water bodies is the Water Quality Index (WQI); while user participation and dealing with uncertainty are required for the evaluation of WQI. The aim of WQI is to convert complicated water quality data to information which can be used and understood by users. This index is vital for users to know the gradation of suitable (fresh) water and unsuitable water which might be poisonous and cause serious diseases sometimes. The index might also be used to test the water quality before drilling water wells which are costly and can be really harmful to the environment; accordingly, costs and risks can be reduced a great deal. Lately, the algorithms of artificial intelligence which are suitable for nonlinear prediction and dealing with uncertain domains have been implemented in different fields of water quality estimation. The purpose of this study is to estimate the water quality index using data sets obtained from 22 camps located in six districts in Duhok city for the period March to August 2018. The data sets contain six water quality parameters which are Nitrates (NO3), Sulphate (SO4), Total Hardness (TH), PH, Total ALkalinity (T. AL) and Calcium (Ca). This paper uses the application of Adaptive Neuro Fuzzy Inference System (ANFIS) for modeling the estimation of water quality index. This model is utilized to train, test and check the index. Statistical criteria such as Mean Squared Error (MSE) and Root Mean Squared Error (RMSE) are used to assess the performance of the ANFIS model. Investigations show that for estimation WQI, the RMSE values are $0.0346,0.2109$ and 0.0403 for training, checking and testing stages, respectively. While, the values of MSE are $0.0012,0.0445$ and 0.0016 for training, checking and testing stages, respectively. Based on the results of the criteria, the ANFIS estimation model has the ability to forecast the water quality index for Duhok camps with reasonable accuracy, and it is useful and valuable for the estimation of WQI.
\end{abstract}

KEYWORDS: Water quality Index, Estimation, ANFIS, Duhok camps, RMSE

\section{INTRODUCTION}

$\mathbf{T}$ The evaluation of water quality is a significant step for the regulatory agencies and for the purpose of protecting different intended uses. In this consideration, the monitoring of continuous water quality is taken in order to evaluate the water quality and suggest sufficient measures for the management of water quality. Water quality index (WQI) considers one of the many ways that can assimilate large quantity of data resulted from the various monitoring stations and it is the easiest way of communication with the stakeholders. The water quality is expressed by aggregating several water quality parameters and the output of aggregation is a single number which is the water quality index. The range of water quality index is from 0 to 100 . A value of 0 is excellent water quality, but 100 is a very poor water quality, this means that the water is unsuitable for the purposed uses (Mohammed \& Mahdi, 2018).

In the 1965, Horton (Horton, 1965) suggested the first water quality index and after that much advancement are noticed in assessing WQI. The form of utilizing soft computing tools, such as artificial intelligence, data mining techniques and fuzzy modeling system, are considered the main focus of these advancements. The traditional techniques of assessing WQI accumulate uncertainties, while the current tools have the ability to care of them (Chau, 2006). To categorize water quality into understandable terms based on the overall index of pollution, various data mining mechanisms such as $\mathrm{k}$ nearest neighbor, support vector machines, and decisions trees have been used by Babbar and Babbar (Babbar and Babbar, 2017). 
AI techniques have been successfully used by different researchers to assess the water quality status. However, the quality and quantity of the data available are the important factors to select the methods. on the other hand, fuzzy logic systems are heuristic systems which utilize if-then rules to make relationships between the input and output parameters (Vernieuwe et al., 2005). However, the major issue in the fuzzy logic system is that there is no procedure to clarify the membership functions, which should be predefined by the human expert about the system. At same time, the main characteristic of artificial neural network (ANN) is to learn adaptively from input and output pairs in an interactive way. A hybrid technique has been created based on these understandings called adaptive neuro fuzzy inference system (ANFIS).

ANFIS becomes a popular technique to deal with uncertain and unknown domains such as water quality estimation. ANFIS takes the advantages of both understandings by embedding the fuzzy logic system into the frame of adaptive networks. The main benefit of the ANFIS over the fuzzy systems is that ANFIS cancels the issue of creating a group of fuzzy if-then rules and specifying the membership functions. The automatic rule generation and parameter optimization in ANFIS are applied using the learning algorithm in ANN. the idea of ANFIS was basically presented by Jang (Jang, 1993) and since then the various water quality issues has successfully implemented the ANFIS technique. Yan et al. (Yan et al., 2010) suggested the comparison between the performance of ANFIS for categorizing the water quality case and ANN. In this study, the Gaussian membership functions were chosen for the proposed model based on the best fit model that contains these membership functions.

Sahu et al. (Sahhu et al., 2011) developed the ANFIS model for forecasting WQI of groundwater. Rahimzadeh et al. (Rahimzadeh et al., 2016) employed the ANFIS technique for the estimation of "oily waste water microfiltration permeates volume". In addition, Talebizadeh and Moridnejad (Talebizadeh and Moridnejad, 2011) made comparison between ANN and ANFIS in predicting the fluctuations of lake level, the ANFIS technique became superior to ANN in terms of competence. In terms of water quality prediction, the prediction of biochemical oxygen demand has implemented ANFIS model based on water quality parameters as inputs (Ahmed and Shah, 2017). In 2018, Khudair (Khudair, 2018) made prediction for the water quality assessment and total dissolved solids using ANN in Iraq. Recently, Polykretis et al. (Polykretis et al., 2019) applied ANFIS to map landslide susceptibility for a Mediterranean catchment. The aim of current study is to develop the ANFIS model for estimating water quality index for Duhok camps based on the six water quality parameters as inputs and then statistical criteria have been used to verify the output of estimation model.

\section{Case Study}

\section{METHODOLOGY}

In this study, water quality data involving six different parameters (Nitrates (NO3), Sulphate (SO4), Total Hardness (TH), PH, Total ALkalinity (T. AL) and Calcium (Ca)) were taken from twenty-two different camps in Duhok province by the Directorate of Water Supply in Duhok city coordinating with the Directorate of Environment in Duhok city and the GIZ organization in 2018. These camps are distributed on the six districts of Duhok province as Shekhan, Akri, Semeel, Bardarash, Zakho and Amedi (See Fig. (1)). The number of the monitored camps varies from a district to another; nine camps were monitored in Semeel, four camps in Zakho, four camps in Shekhan, one camp in Amedi, two in Akre and two camps in Bardarash as shown in Fig. (2). Geographically, Duhok governorate is located in the north of Kurdistan region of Iraq, (43.20 44.10) longitude, $(36.40$ - 37.20) latitude. Concerning the locations of the above mentioned districts in Duhok governorate, Semeel is located in the west, Zakho in the north-west, Shekhan in the south-east, Amedi in the north-east, Akre in the east and Bardarash in the south-east. 


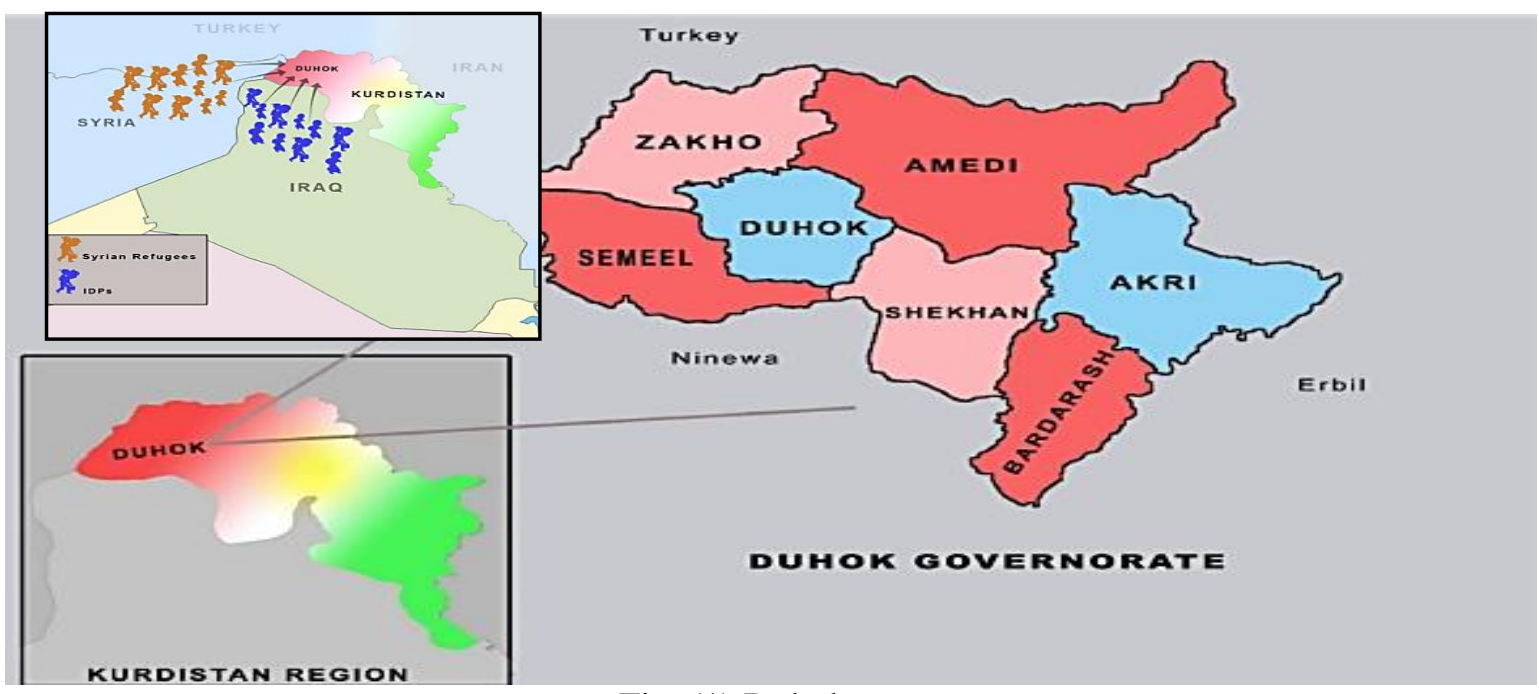

Fig. (1) Duhok map

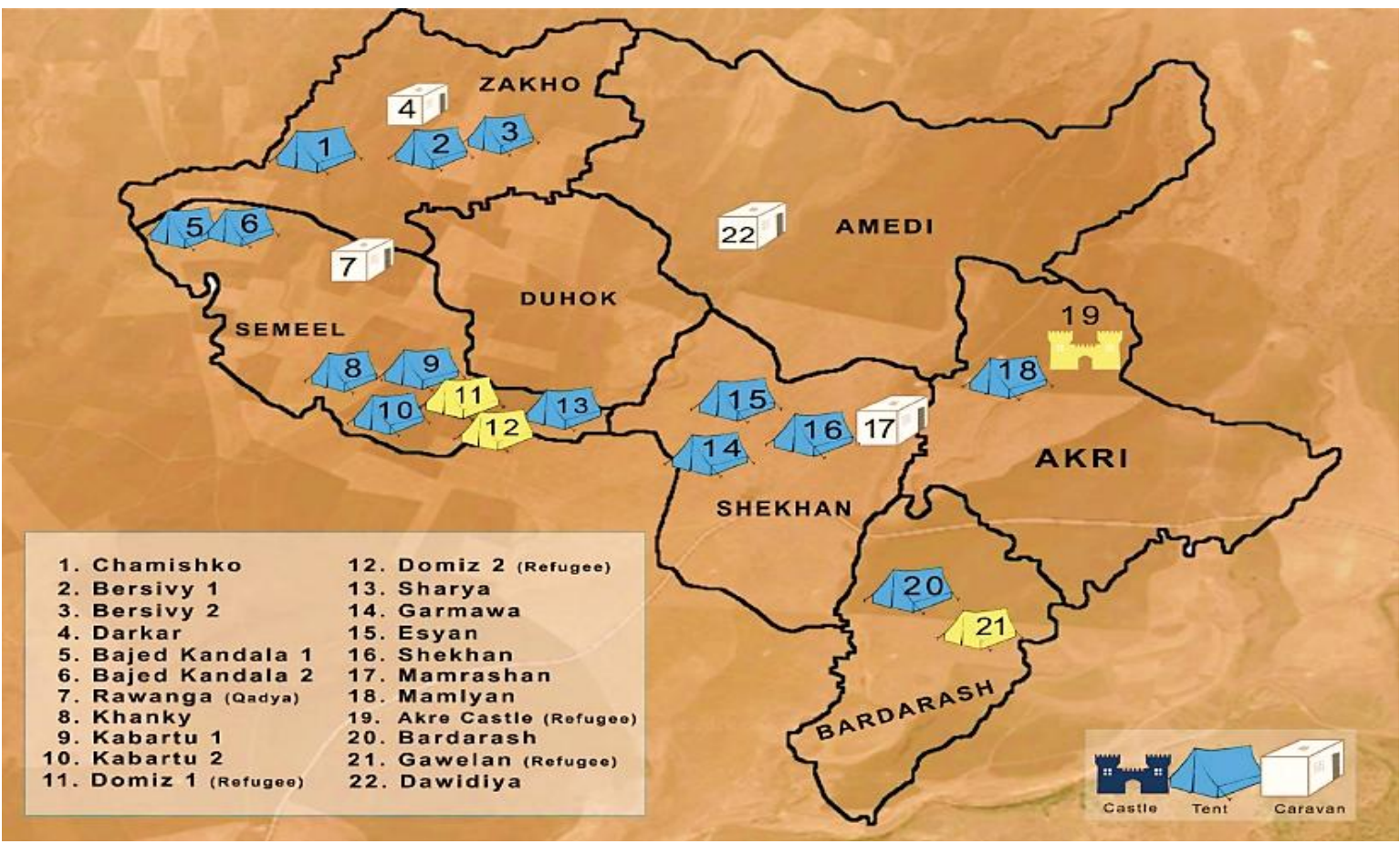

Fig. (2): The locations of the camps in Duhok province

\section{Data Collection}

This study used the data collected by the Directorate of Water Supply in Duhok city coordinating with the Directorate of Environment in Duhok city and The German Society for International Cooperation (GIZ) for the period from March to August 2018. These data were observed on daily basis and analyzed based on the World Health Organization (WHO) (WHO, 2017). The parameters of water quality which are monitored at twenty two camps monitoring sites that are spread in the six districts of the Governorate (Shekhan, Amedi, Semeel,
Bardarash, Zakho and Akri) are Nitrates (NO3), Sulphate (SO4), Total Hardness (TH), PH, Total ALkalinity (T. AL) and Calcium (Ca). For the purpose of analysis 211 samples were chosen for the study.

\section{Water Quality Index}

Water quality index (WQI) is considered as one of the important mechanisms to assess water quality for human uses that identify a classification mechanism which supplies the influence of different water quality parameters on the water quality for various uses, (Rao, 2006). 
The suitability of water quality for human uses can be examined by specifying its index. WQI for drinking water is recommended by the WHO guidelines as standard methods (WHO, 1996) and is calculated using equations suggested by Tiwari and Mishra (Tiwari and Mishea, 1985). To calculate WQI for Duhok camps, six water quality parameters were selected based on their importance and effect, which are $\mathrm{PH}, \mathrm{So} 4$, No3, $\mathrm{Ca}, \mathrm{TH}$ and T.AL. The calculation of WQI used the recommended standard methods for drinking purposes and the values of chosen water quality parameters. There are three steps to evaluate the WQI which are:

1. Each parameter has been given Assigned Weight (AW) according to the studies conducted previously (Alobaidy, 2015; Kangabam, 2017). The table below contains the relative weight, assigned weight and the standard of the six chosen parameters.

Table (1): The relative weight, assigned weight and the standard of the water parameters

\begin{tabular}{cccc}
\hline Parameter & Water quality standard & Assigned weight (AW) & Relative weight (RW) \\
\hline $\mathrm{PH}$ & $6.5-8.5$ & 2.54 & 0.153289077 \\
\hline $\mathrm{NO}_{3}(\mathrm{mg} / \mathrm{l})$ & 50 & 2.57 & 0.155099578 \\
\hline $\mathrm{T} . \mathrm{AL}(\mathrm{mg} / \mathrm{l})$ & $120-200$ & 3 & 0.181050091 \\
\hline $\mathrm{TH}(\mathrm{mg} / \mathrm{l})$ & $100-500$ & 1.46 & 0.088111044 \\
\hline $\mathrm{Ca}(\mathrm{mg} / \mathrm{l})$ & $75-200$ & 2 & 0.12070006 \\
\hline $\mathrm{SO}_{4}(\mathrm{mg} / \mathrm{l})$ & 250 & 5 & 0.301750151 \\
\hline
\end{tabular}

The relative weight is calculated using the below equation:

$$
R W=\frac{A W_{i}}{\sum_{i=1}^{n} A W_{i}}
$$

Where $\mathrm{n}$ is the number of parameters, AW is the assigned weight and RW is the relative weight.

2. The calculation of a quality rating scale $\left(Q_{i}\right)$ for each parameter is performed using the following equation (Eassa and Mahmood, 2012).

$Q_{i}=\frac{\left(C_{i}-V_{i}\right)}{\left(S_{i}-V_{i}\right)} * 100$

Where $Q_{i}$ represents the quality rating scale, $C_{i}$ is the measured value of the water quality parameters, $S_{i}$ is the standard value of the water quality parameter, $V_{i}$ : Ideal value of the ith parameter in pure water; All the ideal values $\left(V_{i}\right)$ are taken as zero for drinking water except for $\mathrm{pH}=7.0$.(Khudair, 2018).

3. The sub-indices $\left(S I_{i}\right)$ is computed by the multiplication of the quality rating scale $\left(Q_{i}\right)$ with the relative weight $(R W)$ as shown below in equation (3):

$$
S I_{i}=R W_{i} * Q_{i}
$$

4. The summation of the sub-indices $(S I)$ produces the $W Q I$ using equation (4):

$$
W Q I=\sum_{i=1}^{n} S I_{i}
$$

The values of WQI were categorized based on the scale suggested by the previous studies, see Table (2).

Table (2): The scale of WQI (Yadav et al., 2010)

\begin{tabular}{cccccc}
\hline WQI & $0-25$ & $26-50$ & $51-75$ & $76-100$ & Above 100 \\
\hline Water quality & Excellent & Good & Poor & Very poor & Unsuitable \\
\hline
\end{tabular}

\section{Description of ANFIS:}

ANFIS links between multilayer neural networks algorithms and fuzzy logic system to map an input into an output (Jang and Sun, 1995). Using learning procedure, ANFIS is able to build an input-output mapping based the first given fuzzy logic system and the available data pairs of input- output (Jang, 1993). A highly nonlinear mapping can be achieved by this system; it is considered superior to others linear methods to produce the best nonlinear time series (Jung et al., 1997). There are two types of fuzzy inference engine systems used in different applications, that process input space into output space, which are 
Mamdani fuzzy inference engine system and Sugeno fuzzy inference engine system (Takagi and Sugen, 1985). Each fuzzy inference system has different outcomes for their fuzzy rules, aggregation and defuzzification methods. Due to the compact and efficient computation of Sugeno system (El-Shafie et al., 2007), Sugeno system is chosen for this study. Figure (3) shows the architecture of a first-order Sugeno system for two rules.

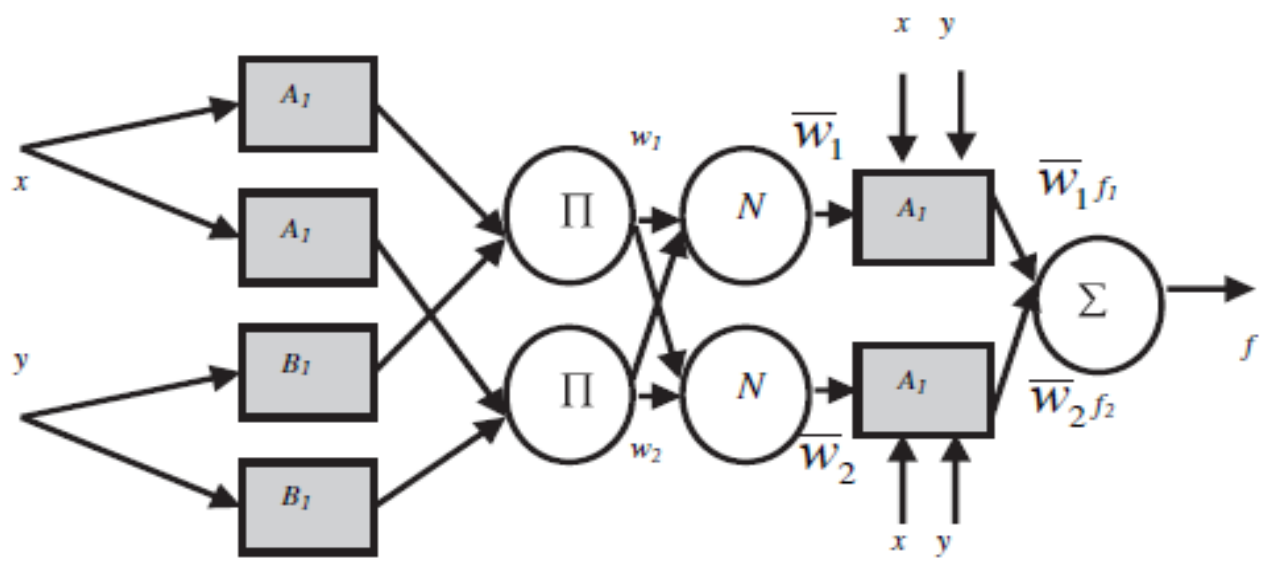

layer $1 \quad$ layer 2 layer 3 layer 4 layer 5

Fig. (3): The architecture of ANFIS equivalent to a first-order Sugeno system

with two inputs and two rules In Sugeno fuzzy inference engine, the output parameter is either a linear equation or constant coefficient (Jung et al., 1997). Suppose that there is a system consists of two inputs entitled $x_{1}$ and $x_{2}$, and one output called y. The fuzzy rule base of the system contains two if-then rules and the representation of the rules for the linear equation as follows:

Rule 1: If $\left(x_{1}=A_{1}\right)$ and $\left(x_{2}=B_{1}\right)$, then

$f_{1}=p_{1} * x_{1}+q_{1} * x_{2}+b_{1}$

Rule 2: If $\left(x_{1}=A_{2}\right)$ and $\left(x_{2}=B_{2}\right)$, then

$f_{2}=p_{2} * x_{1}+q_{2} * x_{2}+b_{2} \ldots \ldots .(5)$

Where $A_{1}, B_{1}, A_{2}, B_{2}$ are fuzzy sets. The consequent part in the above rules contains $p_{i}, q_{i}$ and $b_{i}$ which are the linear parameters of Sugeno FIS. $f_{1}, f_{2}$ are the weighted average.

The ANFIS architecture comprises of five layers. There are many nodes in each layer known as the node function. Adaptive nodes are indicated by squares. Parameters sets, which are adaptable, are represented in these nodes. However, fixed nodes are indicated by circles. Parameter sets, which are fixed, are represented in the system (Kumar, 2011). Each Layer in the architecture of ANFIS is described below:
Layer 1: This layer is called the fuzzification layer. Every node in this layer represents the membership degree of the inputs which is value between 0 and 1 . Every output node $\theta_{i}^{1}$ is calculated by equation (6):

$$
\begin{array}{ll}
\theta_{i}^{1}=\mu_{A_{i}}\left(x_{1}\right) & i=1,2 \\
\theta_{i}^{1}=\mu_{B_{i-2}}\left(x_{2}\right) & i=3,4
\end{array}
$$

Where $x_{1}$ and $x_{2}$ represent the input to the node $i$, $A_{i}$ and $B_{i-2}$ are the linguistic values. The Gaussian membership function is computed as follows

$$
\begin{aligned}
& \mu_{A_{i}}\left(x_{1}\right)=e^{-\left(\left(x_{1}-c_{i}\right)^{2} / 2 \sigma_{i}^{2}\right)} \\
& \mu_{B_{i}}\left(x_{2}\right)=e^{-\left(\left(x_{2}-c_{i}\right)^{2} / 2 \sigma_{i}^{2}\right)}
\end{aligned}
$$

Where $c_{i}$ and $\sigma_{i}$ are the center and width of the fuzzy set $A_{i}\left(\right.$ or $\left.B_{i}\right)$, respectively.

Layer 2: This layer is called the rule layer. Every node in this layer supplies the strength of rules by performing multiplication operator as shown in equation (8). The result of the rule layer is firing strength $\theta_{i}^{2}$ which acts as the product of the membership degree gained from layer 1 . 
$\theta_{i}^{2}=\omega_{i}=$

$\mu_{A_{i}}\left(x_{1}\right) * \mu_{B_{i}}\left(x_{2}\right)$

$i=1,2$

(8)

$\mu_{A_{\mathrm{i}}}\left(x_{1}\right)$ and $\mu_{B_{\mathrm{i}}}\left(x_{2}\right)$ represent the membership degrees and they are multiplied to find the strength of the rule (Kassem et al., 2017).

Layer 3: this layer is named normalization layer which is responsible of normalizing the strength of whole rules based on the following equation:

$\theta_{i}^{3}=\bar{\omega}_{i}=\frac{\omega_{i}}{\sum_{i} \omega_{i}} \quad i=1,2$

Where $\omega_{i}$ is the firing strength of the rule, and $\sum_{i} \omega_{i}$ are the sum of all firing strength of the rules. Layer 4: each node is adaptive node in this layer and the node function defined below in equation (10): $\theta_{i}^{4}=\bar{\omega}_{i} f_{i}=$

$\bar{\omega}_{i}\left(p_{i} * x_{1}+q_{i} * x_{2}+b_{i}\right) \quad i=1,2$

..(10)

Where $\bar{\omega}_{i}$ is the output of the previous layer and $p_{i}, q_{i}, b_{i}$ represents the parameter sets which are indicated as consequent parameters. Layer 5: this layer is called the output layer. The summation of all rules from the layer 4 is taken by the single node to compute the overall output. Consequently, the result of each fuzzy rule is transformed into a crisp output by performing the defuzzification process (Tiwari et al., 2018). The output is calculated using the following equation:

$\theta_{i}^{5}=\gamma=\sum_{i} \bar{\omega}_{i} f=\frac{\sum_{i} \omega_{i} f_{i}}{\sum_{i} \omega_{i}}$

\section{Developed ANFIS Model}

Figure (4) shows the suggested methodology of water quality evaluation in ANFIS.

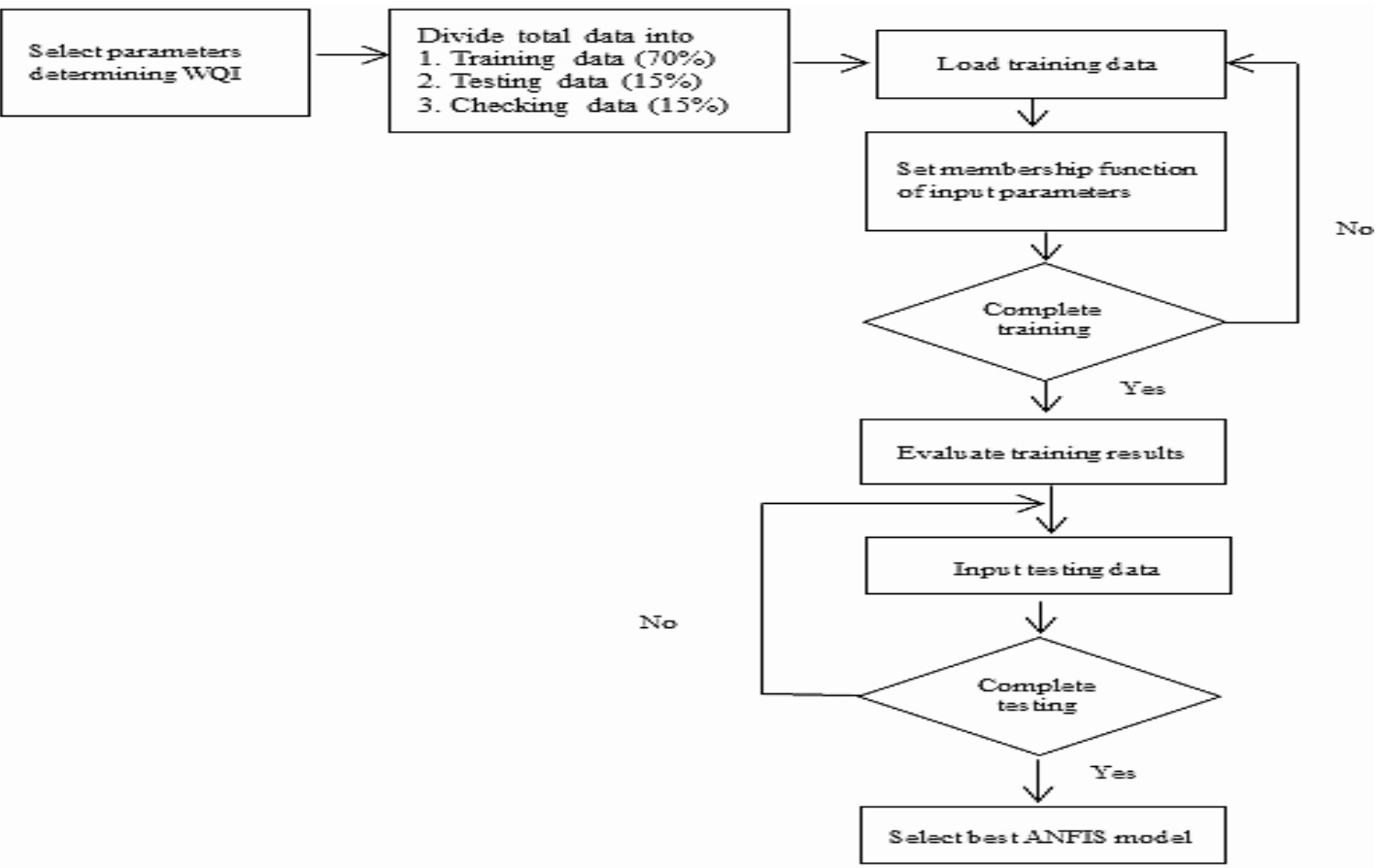

Fig. (4): Flow chart depicting the proposed methodology

In this study, the inputs of the ANFIS are PH, Nitrates $\left(\mathrm{NO}_{3}\right)$, Total Hardness $(\mathrm{TH})$, Total Alkalinity (T.Al), Calcium (Ca) and Sulphate $\left(\mathrm{SO}_{4}\right)$ and the output of ANFIS is the WQI.

The water quality data in this study were obtained from GIZ equaling a total of 211 observations. The data were split into three groups: training group, checking group, and testing group. The ANFIS training used the data of training group, while the ANFIS checking utilized the data of checking group to check the identified ANFIS. The data of testing group were utilized to assess the model performance. 
The training data contained $70 \%$ of the overall data; the testing data used $15 \%$ of the records, while the rest of $15 \%$ data were utilized as checking group. The output is the WQI and its values are calculated by equations (1), (2), (3), (4), respectively. MATLAB Fuzzy Logic Toolbox ANFIS GUI was utilized as a modeling tool for this study. Each input in the proposed system used three Gaussian curve membership functions. In the consequent part of every rule applied a constant defuzzifier method; and the weighting mean of every rule output is computed to get the total output. The hybrid learning algorithm is applied by ANFIS. The algorithm combines two methods which are "the gradient descent back propagation and "least squares" to modify the model variables (Bezdek, 1981).

The calculation of an error measure is the summation of the squared difference between desired and actual output and the value of the error measure for every epoch is reduced. The calculations of fuzzy inference for the developed model were implemented after training. Consequently, the comparison between the result of developed model and the experimental data

To further verify the output, the performance of the developed ANFIS model was evaluated using the two statistical criteria, which are Root Mean Square Error (RMSE), and Mean Square Error (MSE). They are implemented by using equations (12) and (13), respectively.

$$
\begin{aligned}
& \text { RMSE }=\sqrt{\frac{\sum_{i=1}^{n}\left(X_{\text {actual }}-X_{\text {predicted }}\right)^{2}}{n}} \\
& \ldots \ldots \ldots . .(12) \\
& M S E=\frac{\sum_{i=1}^{n}\left(X_{\text {actual }}-X_{\text {predicted }}\right)^{2}}{n}
\end{aligned}
$$

Where $\mathrm{X}_{\text {actual }}$ and $\mathrm{X}_{\text {predicted }}$ are the actual value and predicted values, respectively (Shabani and Mazahery, 2012).

\section{RESULTS AND DISCUSSIONS}

As mentioned in this study, ANFIS approach is used to estimate the water quality index for twenty two camps which are Shekhan, Amedi, Semeel, Bardarash, Zakho and Akri in Duhok city. The estimation of WQI is done for the period March to August 2018 and a total of 211 data sets are utilized for this research. In order to evaluate the performance of ANFIS adequately, the dataset is divided into three parts $(70 \%$ for calculating training accuracy, $15 \%$ for calculating checking accuracy and $15 \%$ for calculating testing accuracy). Six input parameters, $\mathrm{PH}, \mathrm{TH}, \mathrm{Ca}$, $\mathrm{NO}_{3}, \mathrm{SO}_{4}$ and T.AL, are used to calculate the water quality index. Figure (5) shows the difference between the measured and the estimated WQI values for training, checking and testing.

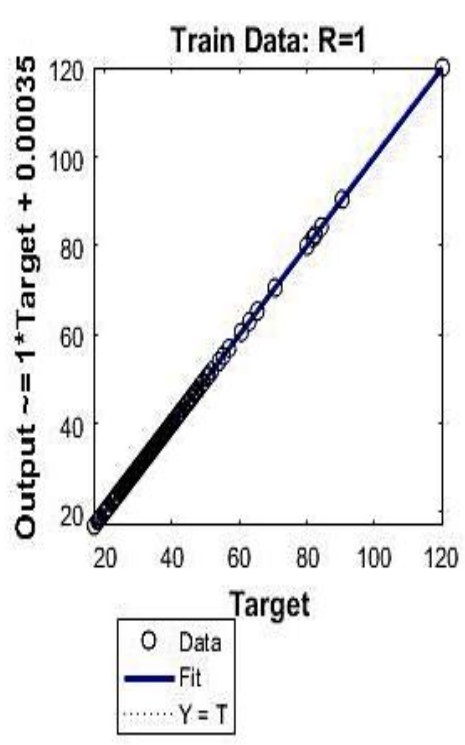

(a) Training Stage

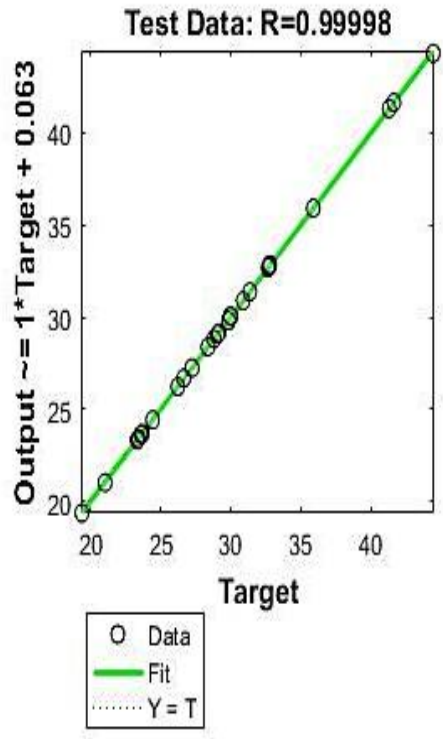

(b) Testing Stage

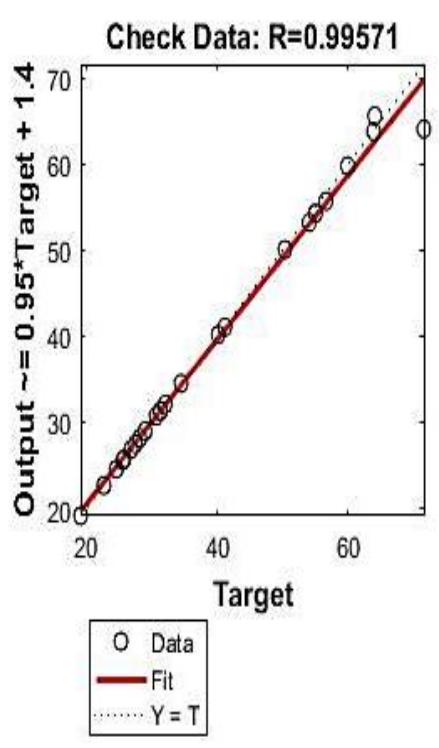

(c) Checking Stage

Fig. (5): Scatter piot tor I ne AIVFIS estimation moueı 
This figure shows that the variation between the measured and estimated WQI for training is 0 , i.e the training accuracy is 1. For checking accuracy, a minor variation occurs between the measured and estimated WQI . This variation lets the checking accuracy to be 0.99571 which is less than the training accuracy. This is an expected result because the data which was used for checking isn't the same as the training's. For testing, the accuracy was also acceptable (0.9998). These accuracies indicate that ANFIS performance significantly efficient for estimating WQI.

Table (3) presents two evaluation metrics that show the confidentiality of ANFIS model, these are the root mean square error (RMSE) and mean square error (MSE) values which are calculated using equations (12) and

(13).

Table (3): The performance parameters of the ANFIS model for test, train and check data

\begin{tabular}{ccll}
\hline & Train Data & Check Data & Test Data \\
\hline RMSE & 0.0346 & 0.2109 & 0.0403 \\
\hline MSE & 0.0012 & 0.0445 & 0.0016 \\
\hline
\end{tabular}

The results in the above table showed that the values of RMSE and MSE were relatively low for training, checking and testing. Less RMSE and MSE mean less difference between the estimated and the actual values. This means that the ANFIS model is efficient and can be used for the WQI estimation.

\section{CONCLUSIONS}

The ANFIS system has performed successfully for predicting WQI. This was evident from the accuracies and the evaluation metrics, figure (5) and table (3). The three accuracies for training, checking and testing are acceptable with very small variations which are due to the variation in dataset parts that have been used for calculating each of these accuracies.

\section{REFERENCES}

- Ahmed, A. M., \& Shah, S. M. A. (2017). Application of adaptive neuro-fuzzy inference system (ANFIS) to estimate the biochemical oxygen demand (BOD) of Surma River. Journal of King Saud University-Engineering Sciences, 29(3), 237-243.

- Al-Obaidy, A. H. M. J., Al-Janabi, Z. Z., \& Shakir, E. (2015). Assessment of water quality of Tigris River within Baghdad City. Mesop. Environ. j, l(3), 90-98.

- Babbar, R., \& Babbar, S. (2017). Predicting river water quality index using data mining techniques. Environmental Earth Sciences, 76(14), 504.
- Bezdek, J. C. (1981). Objective function clustering. In Pattern recognition with fuzzy objective function algorithms (pp. 43-93). Springer, Boston, MA

- Chau, K. W. (2006). A review on integration of artificial intelligence into water quality modelling. Marine pollution bulletin, 52(7), 726-733.

- Eassa, A. M., \& Mahmood, A. A. (2012). An Assessment of the treated water quality for some drinking water supplies at Basrah. Journal of Basrah Researches (Sciences), 38(3A), 95-105.

- Horton, R. K. (1965). An index number system for rating water quality. Journal of Water Pollution Control Federation, 37(3), 300-306.

- Jang, J. S. (1993). ANFIS: adaptive-network-based fuzzy inference system. IEEE transactions on systems, man, and cybernetics, 23(3), 665-685.

- Jang, J. S. (1993). ANFIS: adaptive-network-based fuzzy inference system. IEEE transactions on systems, man, and cybernetics, 23(3), 665-685.

- Jang, J. S. R., Sun, C. T., \& Mizutani, E. (1997). Neuro-fuzzy and soft computing; a computational approach to learning and machine intelligence.

- Jang, J. S., \& Sun, C. T. (1995). Neuro-fuzzy modeling and control. Proceedings of the IEEE, 83(3), 378-406.

- Kangabam, R. D., Bhoominathan, S. D., Kanagaraj, S., \& Govindaraju, M. (2017). Development of a water quality index (WQI) for the Loktak Lake in India. Applied Water Science, 7(6), 29072918.

- Kassem, Y., Çamur, H., \& Esenel, E. (2017). Adaptive neuro-fuzzy inference system (ANFIS) and response surface methodology (RSM) 
prediction of biodiesel dynamic viscosity at 313 K. Procedia Computer Science, 120, 521-528.

- Khudair, B. H. (2018). Water Quality Assessment and Total Dissolved Solids Prediction using Artificial Neural Network in Al-Hawizeh Marsh South of Iraq. Journal of Engineering, 24(4), 147-156.

- Kumar, P. (2011). Crop yield forecasting by adaptive neuro fuzzy inference system. Mathematical Theory and Modeling, 1(3), 1-7.

- Mohammed, J. A. \& Mahi, B. H. (2018). The Prediction of Solar Radiation using Fuzzy Logic: A Case Study. Journal of University of Duhok: Pure and Engineering Sciences, 21(2).

- Polykretis, C., Chalkias, C., \& Ferentinou, M. (2019). Adaptive neuro-fuzzy inference system (ANFIS) modeling for landslide susceptibility assessment in a Mediterranean hilly area. Bulletin of Engineering Geology and the Environment, 78(2), 1173-1187.

- Rahimzadeh, A., Ashtiani, F. Z., \& Okhovat, A. (2016). Application of adaptive neuro-fuzzy inference system as a reliable approach for prediction of oily wastewater microfiltration permeate volume. Journal of environmental chemical engineering, 4(1), 576-584

- Rao, N. S. (2006). Seasonal variation of groundwater quality in a part of Guntur District, Andhra Pradesh, India. Environmental Geology, 49(3), 413-429.

- Sahu, M., Mahapatra, S. S., Sahu, H. B., \& Patel, R. K. (2011). Prediction of water quality index using neuro fuzzy inference system. Water Quality, Exposure and Health, 3(3-4), 175-191.

- Shabani, M. O., \& Mazahery, A. (2012). Artificial intelligence in numerical modeling of nano sized ceramic particulates reinforced metal matrix composites. Applied Mathematical Modelling, 36(11), 5455-5465.

- Takagi, T., \& Sugeno, M. (1985). Fuzzy identification of systems and its applications to modeling and control. IEEE transactions on systems, man, and cybernetics, (1), 116-132.

- Talebizadeh, M., \& Moridnejad, A. (2011). Uncertainty analysis for the forecast of lake level fluctuations using ensembles of ANN and ANFIS models. Expert Systems with Applications, 38(4), 4126-4135.

- Tiwari, S., Babbar, R., \& Kaur, G. (2018). Performance Evaluation of Two ANFIS Models for Predicting Water Quality Index of River Satluj (India). Advances in Civil Engineering, 2018.

- Tiwari, T. N., \& Mishra, M. A. (1985). A preliminary assignment of water quality index of major Indian rivers. Indian J Environ Prot, 5(4), 276279.

- Vernieuwe, H., Georgieva, O., De Baets, B., Pauwels, V. R., Verhoest, N. E., \& De Troch, F. P. (2005). Comparison of data-driven TakagiSugeno models of rainfall-discharge dynamics. Journal of Hydrology, 302(1-4), 173186.

- World Health Organization (WHO. (1996). WHO Guidelines For Drinking Water Quality 2nd Edition.

- World Health Organization. (WHO) (2017). Guidelines for drinking-water quality: first addendum to the fourth edition.

- Yadav, A. K., Khan, P., \& Sharma, S. K. (2010). Water Quality Index Assessment ofGroundwater in Todaraisingh Tehsil of Rajasthan State, IndiaA Greener Approach. Journal of Chemistry, 7(S1), S428-S432.

- Yan, H., Zou, Z., \& Wang, H. (2010). Adaptive Neuro Fuzzy Inference System for Classification of Water Quality Status. Journal of Environmental Sciences, 22(12), 1891-1896. 
باشترين ريّك بو كههاندنا بيّزانينان ل سهر كهيسا ئافئ ز زيّدهريّن ئاثى بو ب كارهيّنهريّن ئافي كو

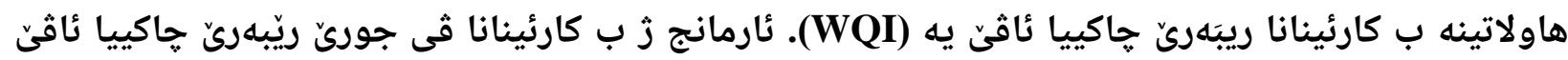

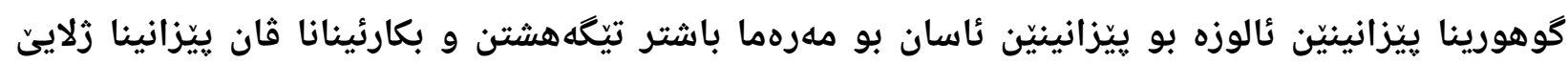

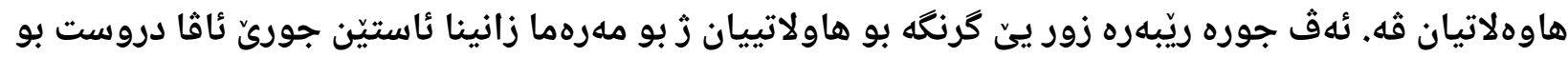

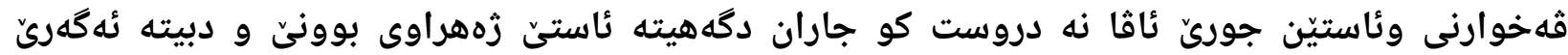
يهيدابوونا زور نه خوشييّن ترسناك. ههروهسا د شيان دايه ئه جو جوره ريّبهره بهيّته بكارئينان زلايتيّ هاولاتييان

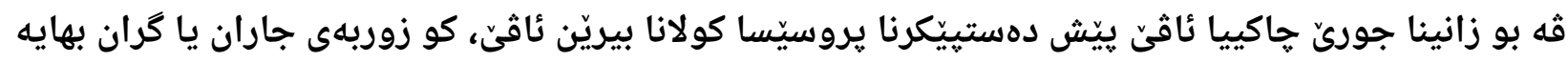

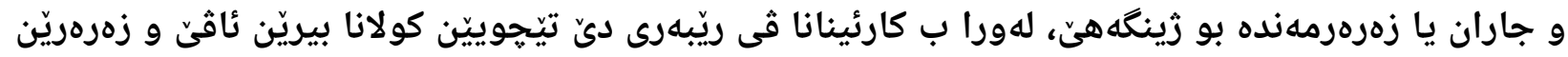

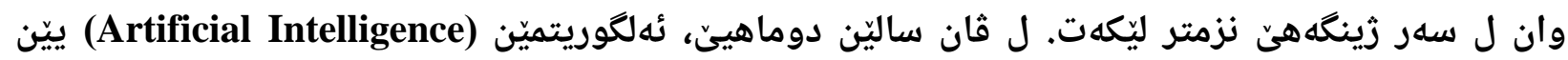

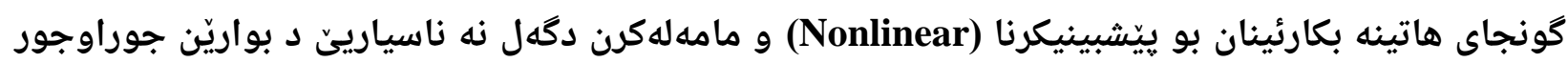

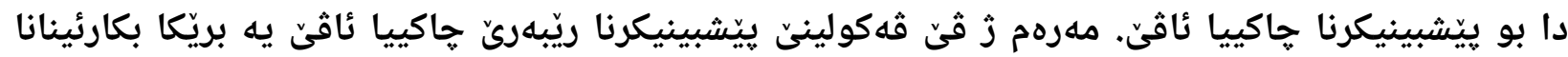

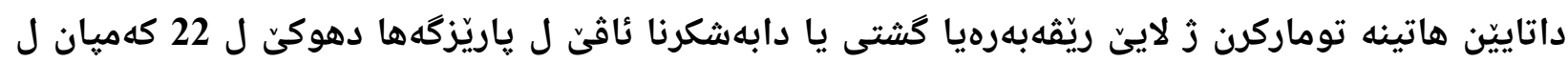

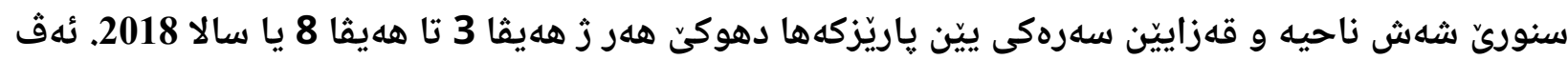

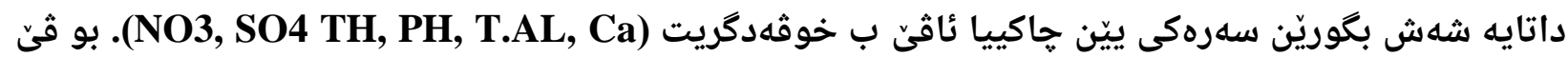

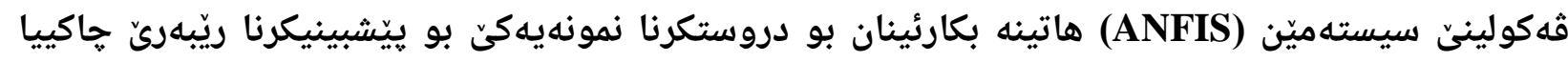

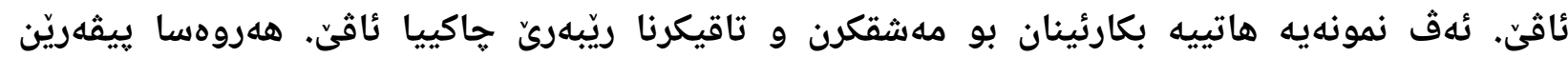

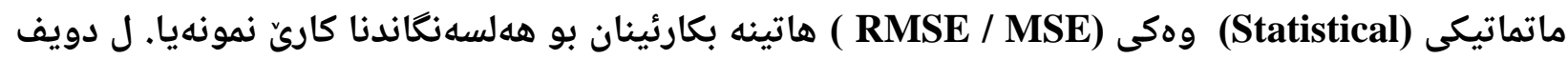

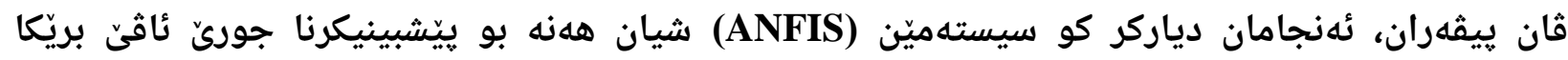

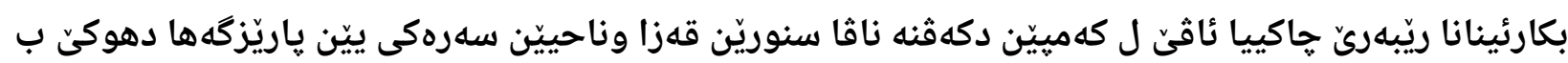

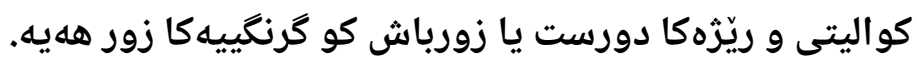


خلاصة

ان انسب طريقة لتوصيل حالة المياه من المسطحات المائية الى المستخدم هي دليل جودة المياه (WQI).الهدف من استخدام دليل جودة المياه هو تحويل المعلومات المعقدة المتعلقة بجودة المياه الى الى معلومات مبسطة قابلة للفهم والاستعمال من قبل المستخدم. هكذا دليل مهم جدا للمستخدم لمعرفة المستويات المختلفة للمياه الصالحة للشرب والمياه الغير صالحة للشرب والتي تصل الى مالى درجة السمية احيانا وتتسبب في امراض خطيرة. يمكن استخدام هذا الدليل من قبل المستخدم لمعرفة جودة المياه قبل القيام عملية حفر الابار والتي تكون مكلفة احيانا و مضرة للبيئة ايضا. وبناء عليه يمكن تقليص التكاليف والمخاطر الى حد كبير. في الاونة الاخيرة تم تنفيذ خوارزميات الذكاء الاصطناعي المناسبة للتخمين الغير خطي والتعامل مع الغموض في مجالات مختلفة من تخمين جودة المياه. الغرض من هذه الدراسة هو تخمين دليل

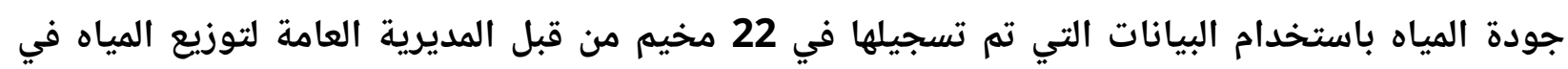

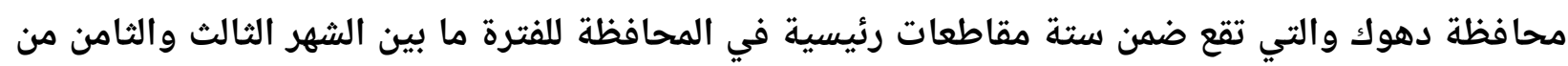

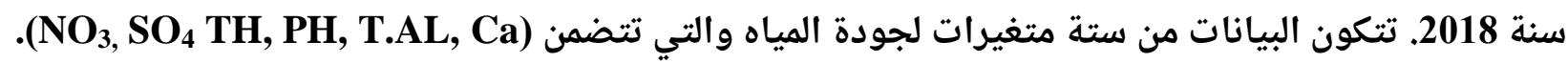
هذه الدراسة تستخدم الأنظمة العصبية الضبابية القابلة للتكيف (ANFIS) لاعداد نموذج لتخمين دليل جودة المياه. تم استخدام هذا النموذج لتدريب وتجربة وفحص دليل جودة المياه. كما تم استخدام المعايير

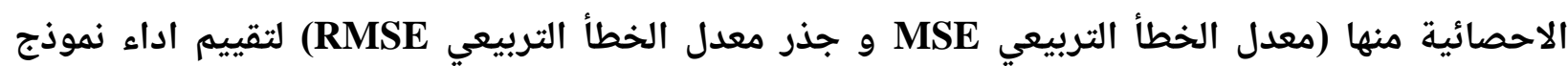
الانظمة العصبية الضبابية القابلة للتكيف. على ضوء نتائج هذه المعايير، تبين ان الانظمة العصبية الغصية الضبابية

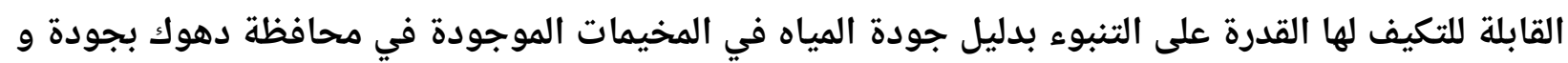
دقة معقولة وهي ذات اهمية كبيرة. 